\title{
SISTEM PREDIKSI PENJUALAN BARANG BEKAS FABRIKASI DI CV. INDRO JAYA DENGAN METODE SINGLE MOVING AVERAGE
}

\author{
Achmad Rifki Rusady ${ }^{1}$, Harunur Rosyid ${ }^{2}$ \\ 1) CV. Indrojaya \\ 2) Teknik Informatika Univeristas Muhammadiyah Gresik \\ E-mail: ruccinimalvoy@gmail.com ${ }^{l}$
}

INTISARI

CV.IndroJaya merupakan jasa steel fabrication di area fabrikasi PT Varia Usaha Gresik. Melayani penjualan barang bekas fabrikasi. CV.IndroJaya dalam hal produksi barang jadi pada bulan berikutnya tidak tahu berapa penjualan barang produksi jadi yang nantinya akan dibutuhkan. Jika terjadi kekurangan persediaan penjualan akan menghambat proses penjualan dari jadwal yang sudah ditentukan. CV.IndroJaya memproduksi barang jadi hanya memperkirakan jumlah produksi tanpa memprediksi permintaan barang produksi. Persediaan, stok dan produksi merupakan salah satu faktor penting dalam menunjang keberlangsungan operasional, untuk mengetahui jumlah produksi pada bulan berikutnya, penelitian ini menggunakan metode Single Moving Average. pengujian berdasarkan orde $3 \times 3$ ( 3 bulan sebelumnya) menghasilkan nilai MAD $=55.407$ dan MAPE $=13 \%$, pengujian kedua dengan orde $4 \times 4$ ( 6 bulan sebelumnya) menghasilkan nilai MAD $=44.907$ dan MAPE $=11,9 \%$, pengujian ketiga dengan orde $6 \times 6$ (12 bulan sebelumnya) menghasilkan nilai MAD $=35.75$ dan MAPE $12 \%$.

Kata Kunci : Single Moving Average, Mean Absolute Deviation, Mean Absolut Percentage Error.

\section{PENDAHULUAN}

CV. Indro Jaya merupakan perusahaan steel fabrication di area fabrikasi PT. Varia Usaha Gresik. CV. Indro Jaya juga melayani penjualan barang bekas fabrikasi dan jasa transport, antara lain besi baja, besi plat, besi beton, alumunium, kabel tembaga, material besi, mesin tua, kaleng cat mesin, pipa konstruksi, as besi, kanal CNP dan lainlain.

Permasalahan CV. Indro Jaya adalah dalam hal menentukan penjualan barang bekas fabrikasi bulan berikutnya, dikarenakan CV. Indro Jaya tidak mengetahui berapa banyak penjualan barang bekas fabrikasi pada bulan berikutnya, serta untuk antisipasi apabila terjadi kekurangan stok dalam penjualan yang mengakibatkan terhambatnya proses penjualan barang bekas fabrikasi. Apabila terjadi kelebihan pembelian dapat menimbulkan kemungkinan timbulnya biaya untuk menyimpan kelebihan persediaan barang bekas fabrikasi tersebut. Selama ini CV. Indro Jaya membeli persedian barang bekas fabrikasi tanpa memprediksi penjualan di bulan berikutnya, dimana sering terjadi kerugian karena terlalu banyaknya persediaan barang bekas fabrikasi di dalam gudang.

Diperlukan suatu sistem yang dapat membantu memprediksi penjualan ke depan dengan lebih objektif dengan memperhatikan data penjualan bulan lalu untuk prediksi penjualan bulan depan. Dari permasalahan yang ada nantinya akan dibuat sebuah sistem prediksi untuk memprediksi penjualan barang bekas fabrikasi pada bulan berikutnya.

Beberapa metode peramalan seperti analisis time series sering digunakan dalam melakukan peramalan terhadap data-data historis, dalam mengamati data penjualan produk. Dalam analisa data time series, dikenal beberapa model peramalan seperti model Auto Regresi (AR), moving average (MA), Auto Regresi Moving Average (ARMA). Tujuan utama penggunaan teknik moving average 
adalah untuk mengurangi atau mengeleminasi variasi acak penjualan dalam hubungannya dengan waktu (Diana, dkk. 2015).

Penelitian yang dilakukan oleh Alfian Nurlifa pada tahun 2017 yang membahas Single Moving Average, digunakan untuk meramal penjualan di Rumah Jilbab Rizky. Pada penelitian tersebut dengan data yang digunakan, data tersebut memiliki kemiripan dengan data yang akan digunakan pada penelitian yang akan dilakukan, dan dapat di implementasikan dengan baik. Sehingga dengan menggunakan metode Single Moving Average, diharapkan dapat membantu mengatasi permasalahan yang ada di CV.Indro Jaya.

\section{LANDASAN TEORI}

\subsection{Pengertian Peramalan (Forecasting)}

Peramalan (forecasting) adalah seni dan ilmu untuk memperkirakan kejadian dimasa depan. Hal ini dapat dilakukan dengan melibatkan pengambilan data masa lalu dan menempatkannya kemasa yang akan datang dengan suatu bentuk model matematis. Peramalan, prediksi (forecasting) merupakan alat penting dalam pengambilan kesimpulan. Kualitas suatu ramalan berkaitan erat dengan informasi yang dapat diserap dari data masa lampau (Boedijoewono, 2001).

Kegiatan peramalan merupakan bagian integral dari pengambilan keputusan manajemen. Peramalan mengurangi ketergantungan pada halhal yang belum pasti (intuitif). Peramalan memiliki sifat saling ketergantungan antar divisi atau bagian. Kesalahan dalam proyeksi penjualan akan mempengaruhi pada ramalan anggaran, pengeluaran operasi, arus kas, persediaan, dan sebagainya.

Dua hal pokok yang harus diperhatikan dalam proses peramalan yang akurat dan bermanfaat :

1. Pengumpulan data yang relevan berupa informasi yang dapat menghasilkan peramalan yang akurat.

2. Pemilihan teknik peramalan yang tepat yang akan memanfaatkan informasi data yang diperoleh semaksimal mungkin.

Terdapat dua pendekatan untuk melakukan peramalan yaitu dengan pendekatan kualitatif dan pendekatan kuantitatif. Metode peramalan kualitatif digunakan ketika data historis tidak tersedia. Metode peramalan kualitatif adalah metode subyektif (intuitif). Metode ini didasarkan pada informasi kualitatif. Dasar informasi ini dapat memprediksi kejadian-kejadian di masa yang akan datang. Keakuratan dari metode ini sangat subjektif

Metode peramalan kuantitatif dapat dibagi menjadi dua tipe, causal dan time series. Metode peramalan causal meliputi faktor-faktor yang berhubungan dengan variabel yang diprediksi seperti analisis regresi. Peramalan time series merupakan metode kuantitatif untuk menganalisis data masa lampau yang telah dikumpulkan secara teratur menggunakan teknik yang tepat. Hasilnya dapat dijadikan acuan untuk peramalan nilai di masa yang akan datang.

\subsection{Analisis Deret Berkala (Time Series)}

Deret Berkala adalah data yang disusun berdasarkan urutan waktu terjadinya dan menggambarkan perkembangan suatu kejadian atau suatu kegiatan. Data masa lampau ini dicatat dalam interval waktu satu tahun, satu semester, satu kuartal, satu triwulan, bulanan, harian dan satuan waktu lainnya. Analisis Deret Berkala (Time Series Analysis) adalah suatu metode kuantitatif untuk menentukan pola data masa lampau yang telah dikumpulkan secara teratur. Apabila kita telah menemukan pola data masa lampau, maka kita dapat menggunakannya untuk mengadakan peramalan di masa yang akan datang. (Boedijoewono, 2001).

Variabel deret berkala dipengaruhi oleh empat gerakan atau perubahan yang disebut komponenkomponen deret berkala. Keempat komponen deret berkala tersebut adalah:

1. Trend Sekuler, yaitu gerakan yang berjangka panjang, lamban, seolah-olah alun ombak dan berkecenderungan menuju ke satu arah menaik atau menurun.

2. Variasi Musiman, yaitu gerak naik atau turun secara periodic dalam jangka waktu kurang dari satu tahun.

3. Variasi Siklis, yaitu gerak naik atau turun secara periodic didalam jangka waktu panjang, misalnya 5 tahun, 10 tahun, 20 tahun, 25 tahun atau lebih.

4. Variasi Random, yaitu gerakan yang tidak teratur sama sekali. 
Trend Linear memiliki persamaan yang secara umum dapat dinyatakan sebagai berikut: (Riana Dwiza, 2012)

$\mathrm{Y}=\mathrm{a}+\mathrm{bX}$

Keterangan:

$$
\begin{aligned}
& \mathrm{Y}: \text { nilai trend pada periode tertentu } \\
& \mathrm{X}: \text { periode waktu } \\
& \mathrm{a}: \text { intersep dari persamaan trend } \\
& \mathrm{b}: \text { koefsien kemiringan atau gradien dari } \\
& \text { persamaan trend yang menunjukkan } \\
& \text { besarnya suatu perubahan suatu unit } \\
& \text { pada } \mathrm{X}
\end{aligned}
$$

Ada empat cara/ metode yang biasa digunakan untuk menyusun atau menentukan trend linear, yaitu :

1. Metode Bebas (Freehand Method)

2. Metode Semi Rata-rata (Semi Average Method)

3. Metode Rata-rata Bergerak (Moving Average Method)

4. Metode Kuadrat Terkecil (Least Square Method)

\subsection{Metode Rata-rata Bergerak tunggal (Single} Moving Average Method)

Rata-rata bergerak tunggal (Single Moving Average) adalah suatu metode peramalan yang dilakukan dengan mengambil sekelompok nilai pengamatan, mencari nilai rata-rata tersebut sebagai ramalan untuk periode yang akan datang. Metode Single Moving Average mempunyai karakteristik khusus yaitu ;

1. untuk menentukan ramalan pada periode yang akan datang memerlukan data historis selama jangka waktu tertentu. Misalnya, dengan 3 bulan moving average, maka ramalan bulan ke 5 baru dibuat setelah bulan ke 4 selesai/berakhir. Jika bulan moving averages bulan ke 7 baru bisa dibuat setelah bulan ke 6 berakhir.

2. Semakin panjang jangka waktu moving average, efek pelicinan semakin terlihat dalam ramalan atau menghasilakan moving average yang semakin halus.
Persamaan matematis single moving averages adalah sebagai berikut :

$$
\mathrm{M}_{\mathrm{t}}=\mathrm{F}_{\mathrm{t}+1}=\frac{\mathrm{Yt}+\mathrm{Yt}-1+\mathrm{Yt}-2+\cdots+\mathrm{Yt}-\mathrm{n}+1}{n}
$$

Dimana:

Mt = Moving Average untuk periode $\mathrm{t}$

$\mathrm{F}_{\mathrm{t}+1}=$ Ramalan Untuk Periode $\mathrm{t}+1$

Yt $=$ Nilai Aktual periode ke $\mathrm{t}$

$\mathrm{n}=$ Jumlah batas dalam moving average

\subsection{Pengukuran Kesalahan Peramalan}

Sebuah notasi matematika dikembangkan untuk menunjukkan periode waktu yang lebih spesifik karena metode kuantitatif peramalan sering kali memperlihatkan data runtun waktu. Huruf $Y$ akan digunakan untuk menotasikan sebuah variabel runtun waktu meskipun ada lebih dari satu variabel yang ditunjukkan. Periode waktu bergabung dengan observasi yang ditunjukkan sebagai tanda. Oleh karena itu, $Y_{t}$ menunjukkan nilai dari runtun waktu pada periode waku $t$.

Notasi matematika juga harus dikembangkan untuk membedakan antara sebuah nilai nyata dari runtun waktu dan nilai ramalan. $\hat{A}$ akan diletakkan di atas sebuah nilai untuk mengindikasi bahwa hal tersebut sedang diramal. Nilai ramalan untuk $Y_{t}$ adalah $\hat{Y}_{t}$. Ketepatan dari teknik peramalan sering kali dinilai dengan membandingkan deret asli $Y_{l}, Y_{2}$, ... dengan deret nilai ramalan $\hat{Y}_{1}, \hat{Y}_{2}, \ldots$

Beberapa metode lebih ditentukan untuk meringkas kesalahan (error) yang dihasilkan oleh fakta (keterangan) pada teknik peramalan. Sebagian besar dari pengukuran ini melibatkan rata-rata beberapa fungsi dari perbedaan antara nilai aktual dan nilai peramalannya. Perbedaan antara nilai observasi dan nilai ramalan ini sering dimaksud sebagai residual.

Persamaan dibawah ini digunakan untuk menghitung error atau sisa untuk tiap periode peramalan.

$e_{t}=Y_{t}-\hat{Y}_{t}$

Dimana :

$e_{t}$ : error ramalan pada periode waktu $\mathrm{t}$ 
$Y_{t}$ : nilai aktual pada periode waktu t.

$\hat{Y}_{t}$ : nilai ramalan untuk periode waktu t.

Satu metode untuk mengevaluasi metode peramalan menggunakan jumlah dari kesalahankesalahan yang absolut. Mean Absolute Deviation (MAD) mengukur ketepatan ramalan dengan merata-rata kesalahan dugaan (nilai absolut masing-masing kesalahan). MAD paling berguna ketika orang yang menganalisa ingin mengukur kesalahan ramalan dalam unit yang sama dengan deret asli.

$\operatorname{MAD}=\frac{1}{n} \sum_{t=1}^{n} \mid Y_{t}-$ $\hat{Y}_{t} \mid \ldots$

Ada kalanya persamaan ini sangat berguna untuk menghitung kesalahan-kesalahan peramalan dalam bentuk persentase daripada jumlah. Mean Absolute Percantage Error (MAPE) dihitung dengan menggunakan kesalahan absolut dari tiap periode dibagi dengan nilai observasi yang nyata untuk periode itu. Kemudian merata-rata kesalahan persentase absolut tersebut. Pendekatan ini berguna ketika ukuran atau besar variabel ramalan itu penting dalam mengevaluasi ketepatan ramalan. MAPE dapat dihitung dengan rumussebagai berikut.

$$
\text { MAPE }=\frac{1}{n} \sum_{t=1}^{n}\left|Y_{t}-\hat{Y}_{t}\right| /
$$

\section{III.ANALISIS DAN PERANCANGAN SISTEM}

\subsection{Hasil Analisis}

Analisa penjualan barang bekas fabrikasi di $\mathrm{CV}$. Indro Jaya dalam menyelesaikan permasalahan penentuan ketepatan memprediksi penjualan barang bekas fabrikasi maka dibutuhkan peran sebuah sistem peramalan penjualan yang dapat membantu dalam pengadaan barang yang akan dijual karena dapat mengetahui beberapa penjualan pada periode yang akan datang.

Sistem yang akan dibangun termasuk ke dalam sistem peramalan (forecasting). Sistem ini harus mampu memprediksi penjualan barang bekas fabrikasi untuk bulan selanjutnya berdasarkan data dari bulan-bulan sebelumnya. Peramalan atau forecasting adalah data di masa lalu yang digunakan untuk keperluan estimasi data yang akan datang. Dengan kata lain, peramalan merupakan suatu dugaan terhadap permintaan yang akan datang berdasarkan pada beberapa variabel peramal, sering berdasarkan data deret waktu historis (Gasperzs, 2005).

Sistem peramalan digunakan oleh pihak manajemen dan Divisi penjualan (Sales Management) untuk menentukan keputusan berdasarkan prediksi yang diberikan oleh sistem. Berdasarkan hal tersebut, sistem ini terdiri dari 3 entitas, yaitu:

1. Administrasi : merupakan entitas yang bertanggung jawab penuh terhadap berjalannya sistem sesuai dengan tujuan pengembangan sistem itu sendiri.

2. Divisi Penjualan : berkaitan dengan bagaimana sebuah perusahaan akan menjual barangbarang hasil produksinya. Tanggung jawab entitas ini adalah memasukan data per bulan.

3. Manager : pihak manager beranggung jawab mengambil keputusan berdasarkan peramalan yang dilakukan sistem. Pihak manager dapat melihat laporan hasil peramalan sistem.

Sistem yang akan dikembangkan untuk membantu CV. Indro Jaya Gresik memprediksi penjualan menerapkan metode Single Moving Average. Rata-rata bergerak tunggal atau Single Moving Average adalah suatu metode peramalan yang dilakukan dengan mengambil sekelompok nilai pengamatan, mencari nilai rata-rata tersebut sebagai ramalan untuk periode yang akan datang. Penggunaan metode Single Moving Average adalah untuk mengurangi data yang bersifat acak (randomness) dalam deret berkala (Martiningtyas, 2004:105).

Secara umum, proses dalam sistem prediksi penjualan barang bekas fabrikasi di CV. Indro Jaya Gresik pada gambar 3.1 dibawah ini. 


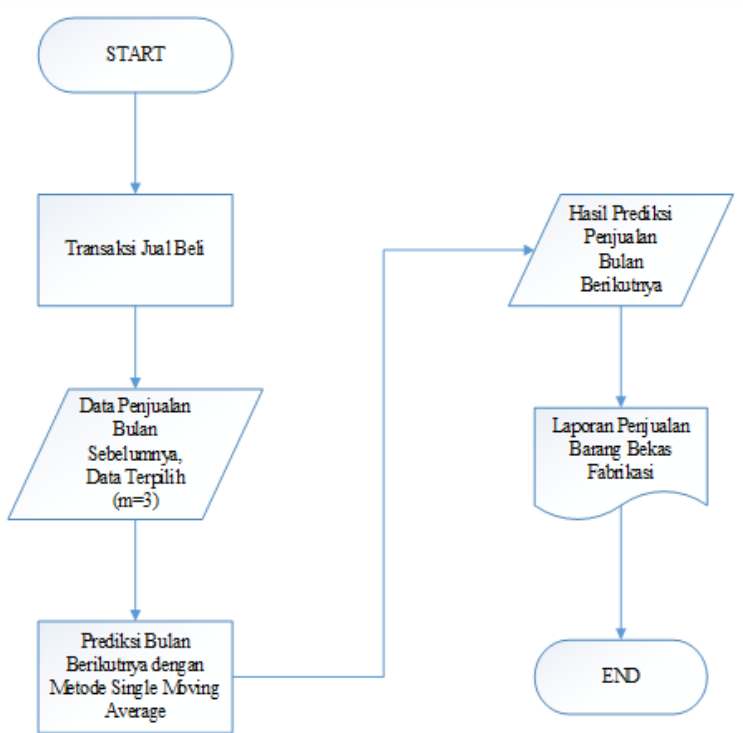

Gambar 3.1 Flowchart Sistem Prediksi Penjualan

Barang Bekas Fabrikasi di CV. Indro Jaya Gresik

Berdasarkan gambar 3.1, proses prediksi penjualan barang bekas fabrikasi dimulai dengan transaksi jual beli yang dilakukan oleh customer dengan Divisi penjualan. Kemudian mengambil data penjualan sebelumnya untuk memilih bulan terpilih $(\mathrm{m}=3)$ yang digunakan dalam prediksi penjualan bulan berikutnya dengan menggunakan metode Single Moving Average yang kemudian mengetahui hasil prediksi penjualan barang bekas fabrikasi pada bulan berikutnya.

Berikut merupakan diagram alir perhitungan metode Single Moving Average :

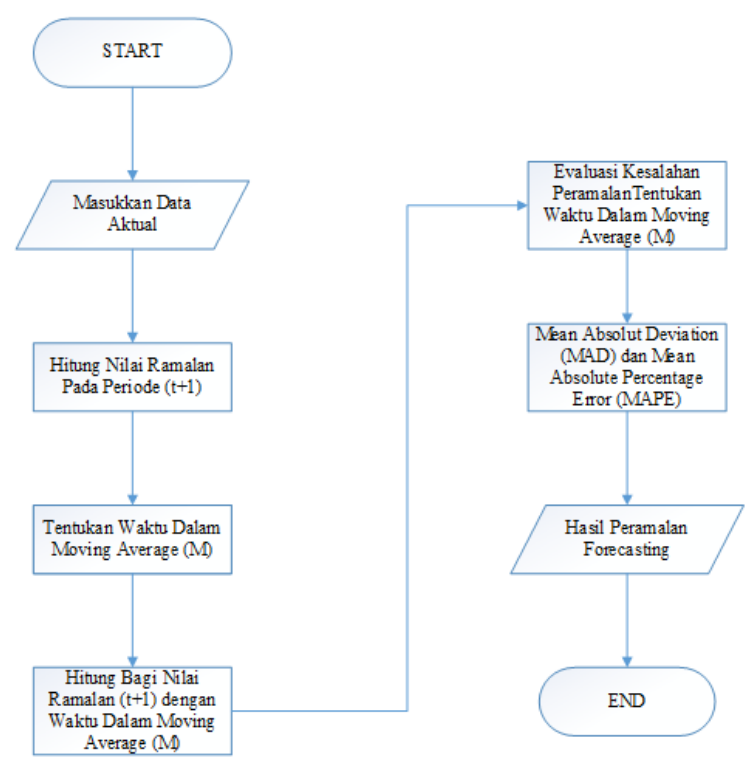

Gambar 3.2 Diagram Alir Metode Single Moving Average

\subsection{Diagram Konteks}

Diagram konteks adalah diagram yang terdiri dari suatu proses dan menggambarkan ruang lingkup suatu sistem. Diagram konteks merupakan level tertinggi dari DFD yang menggambarkan seluruh input ke sistem dan output dari sistem.

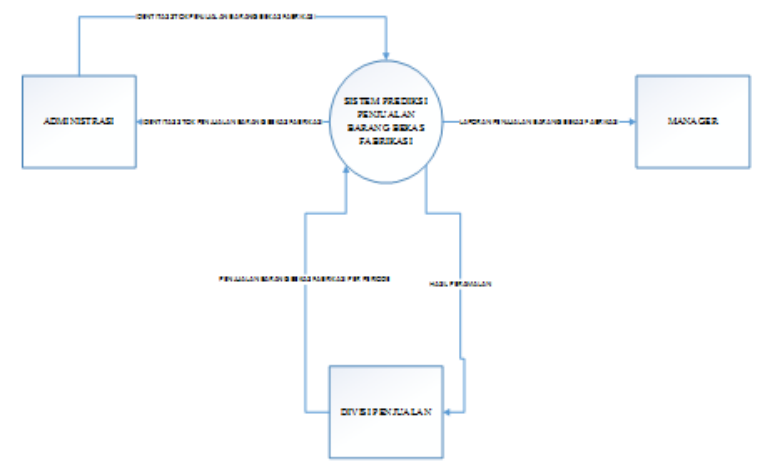

Gambar 3.3 Diagram Konteks Sistem Prediksi

Penjualan Barang Bekas Fabrikasi

Pada Diagram konteks Gambar 3.3 merupakan gambaran sistem secara garis besar, dimana terdapat tiga entitas luar yang berhubungan dengan sistem, yaitu :

1. Administrasi merupakan pihak yang mengolah identitas pelanggan, mengolah stok penjualan barang bekas fabrikasi, dan memperoleh info identitas pelanggan dan memperoleh info stok penjualan barang bekas fabrikasi.

2. Divisi Penjualan merupakan pihak yang memasukkan data berupa penjualan per bulan dan memperoleh hasil peramalan

3. Manager merupakan pihak yang dapat melihat hasil laporan penjualan barang bekas fabrikasi.

\subsection{Diagram Berjenjang}

Dalam pembuatan sistem prediksi diperlukan bagan berjenjang, dimana merupakan awal dari penggambaran Data Flow Diagram (DFD) ke level-level lebih bawah lagi. Dari sistem pendukung keputusan ini mempunyai 3 (tiga) level seperti yang terlihat di gambar 3.4 


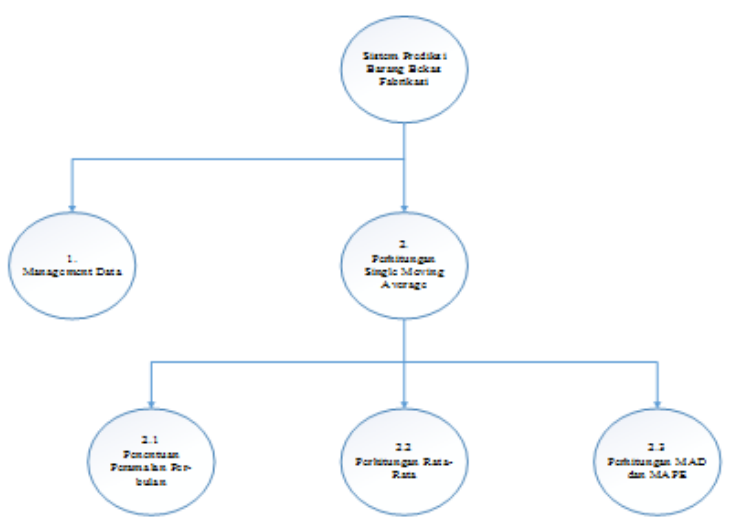

Gambar 3.4 Diagram Berjenjang Sistem Prediksi Penjualan Barang Bekas Fabrikasi

Pada gambar 3.5 dapat dijelaskan sebagai berikut:
1. Top Level : Sistem Prediksi
Penjualan Barang Bekas Fabrikasi

2. Level 0 :1. Management Data

2. Perhitungan Single

Moving Average

3. Level 1 : 2.1 Penentuan peramalan per bulan

2.2 Perhitungan rata-rata

2.3 Perhitungan MAD dan MAPE

\subsection{Data Flow Diagram (DFD) Level 0}

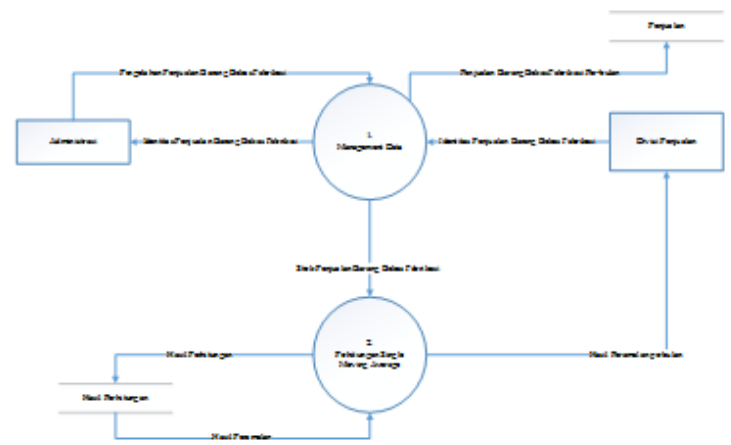

Gambar 3.5 DFD Level 0 Sistem Prediksi Penjualan Barang Bekas Fabrikasi

DFD level 0 yang ditunjukan pada Gambar 3.5, menjelaskan beberapa proses yang terjadi pada sistem prediksi penjualan barang bekas fabrikasi dimana proses tersebut terbagi menjadi 3 proses yaitu : Management Data, Perhitungan Single Moving Average, dan Laporan. Setiap stake holder memiliki peranan masing-masing dalam jalannya sistem. Output dari sistem adalah prediksi penjualan barang bekas fabrikasi pada bulan berikutnya yang nantinya akan dibuatkan laporan dari hasil peramalan yang telah dilakukan kepada manager.

\subsection{Data Flow Diagram (DFD) Level 1}

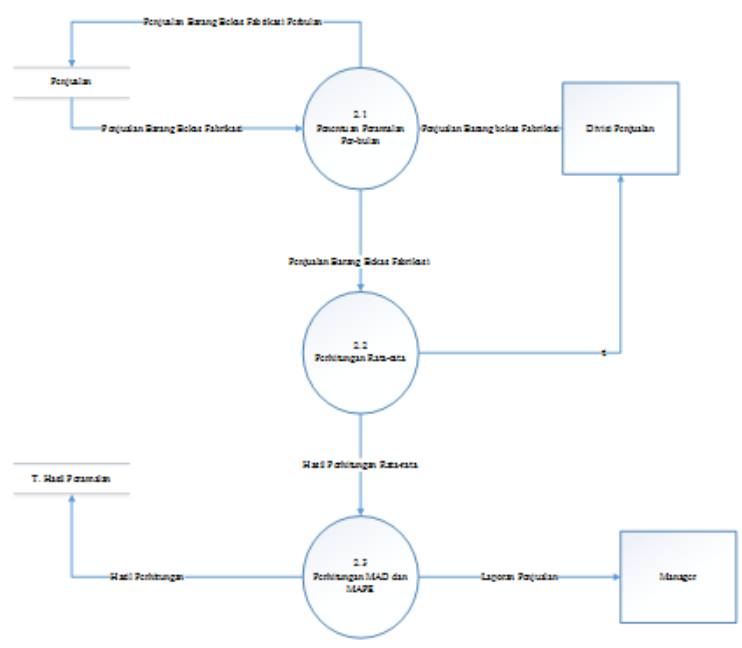

Gambar 3.6 DFD Level 1 Sistem Prediksi Penjualan Barang Bekas Fabrikasi

Adapun keterangan dari Gambar 3.7 di atas ini adalah sebagai berikut :

1. Proses 2.1 adalah proses menghitung peramalan per bulan. Data yang digunakan adalah data yang bulan sebelumnya yang telah dimasukkan ke dalam tabel penjualan.

2. Proses 2.2 adalah proses menghitung nilai rata-rata terhadap periode waktu yang nantinya akan digunakan untuk mencari nilai peramalan.

3. Proses 2.3 adalah proses menghitung nilai MAD dan MAPE yang nantinya mengukur kesalahan ramalan dari hasi permalan tersebut.

\section{IMPLEMENTASI DAN PENGUJIAN SISTEM 4.1 Implementasi Sistem}

\subsubsection{Halaman Login}

Halaman login merupakan halaman pertama pada sistem ini. Pada halaman login terdapat form dengan 2 isian yaitu username dan password yang harus diisi dengan benar agar dapat masuk kedalam 
INDEXIA: Informatic and Computational Intelegent Journal

Achmad Rifki Rusady, Harunur Rosyid

Sistem Prediksi Penjualan Barang Bekas Fabrikasi Di Cv. Indro Jaya Dengan Metode Single Moving Average

sistem. Halaman login dapat dilihat pada Gambar 4.1

\section{Login CV. Indro Jaya}

SISTEM PREDIKSI

PENJUALAN

BARANG BEKAS FABRIKASI

\section{Username}

Password

\section{Login}

\section{Gambar 4.1 Halaman Login}

\subsubsection{Halaman Home}

Halaman home merupakan halaman yang berisi informasi tentang sistem prediksi jumlah Penjualan barang bekas fabrikasi di CV.Indrojaya. Halaman home dapat dilihat pada Gambar 4.2.

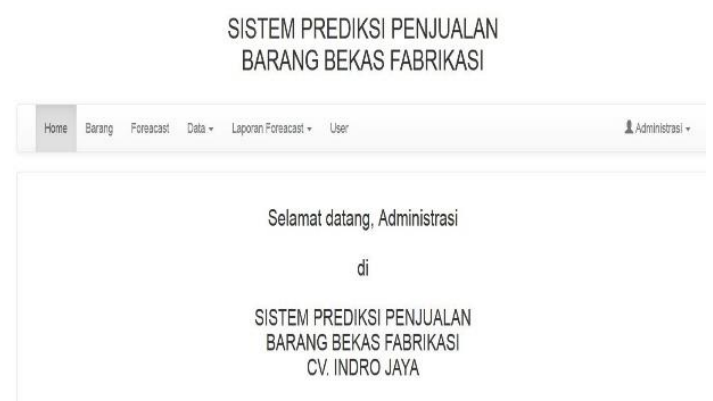

Gambar 4.2 Halaman Home

\subsubsection{Halaman Data Penjualan}

Data penjualan merupakan halaman yang berisi data-data penjualan barang bekas fabrikasi terbaru. Pada halaman ini admin bisa menambahkan data barang. Halaman data Penjualan dapat dilihat pada Gambar 4.3.

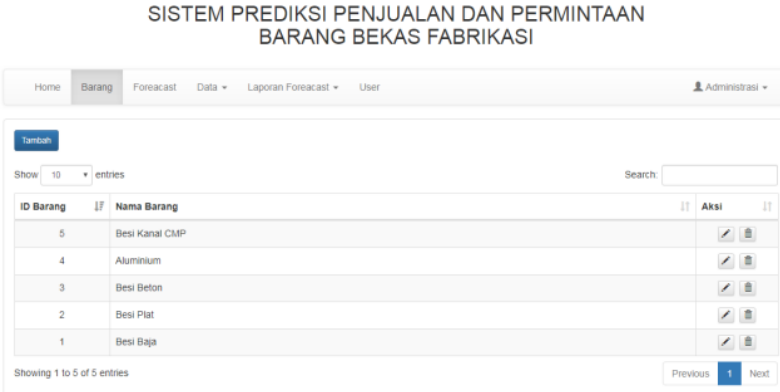

Gambar 4.3 Halaman Data Penjualan

\subsubsection{Tambah Data Penjualan}

Halaman ini digunakan untuk memprediksi penjualan barang bekas fabrikasi pada bulan selanjutnya dan halaman forecast penjualan dapat dilihat. Pada tahap pengujian sistem akan dilakukan penginputan data awal sebagai aktual. Data aktual tersebut bertujuan sebagai acuan untuk memprediksi penjualan besi di bulan selanjutnya. Setelah menginputkan data aktual per periode penjualan besi kemudian kita dapat melakukan proses penghitungan prediksi dengan Single Moving Average.

\section{SISTEM PREDIKSI PENJUALAN BARANG BEKAS FABRIKASI}
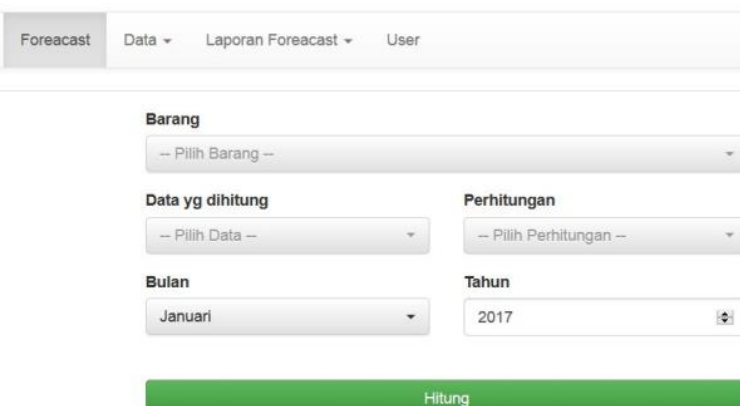

Gambar 4.4 Halaman Forecast Penjualan

\subsubsection{Data Tambah Forcast}

Proses perhitungan berjalan saat setelah kita memilih barang, data yang dihitung menentukan bulan yang akan diprediksi dan menentukan periode perhitungan kemudian menekan tombol proses untuk proses forecasting. Lihat pada Gambar 4.5 sebagai berikut 


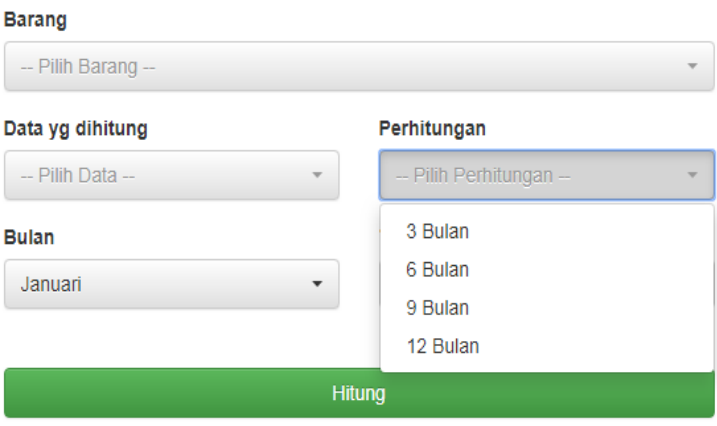

Gambar 4.5 Halaman Penentuan Orde Periode Desember 2017 dengan Orde 3x3 (3 bulan sebelumnya)

Pada contoh dalam pengujian perhitungan forecast per 3 bulan periode untuk menghitung forecast pada periode Januari 2016 Lihat pada sebagai berikut Gambar 4.6.

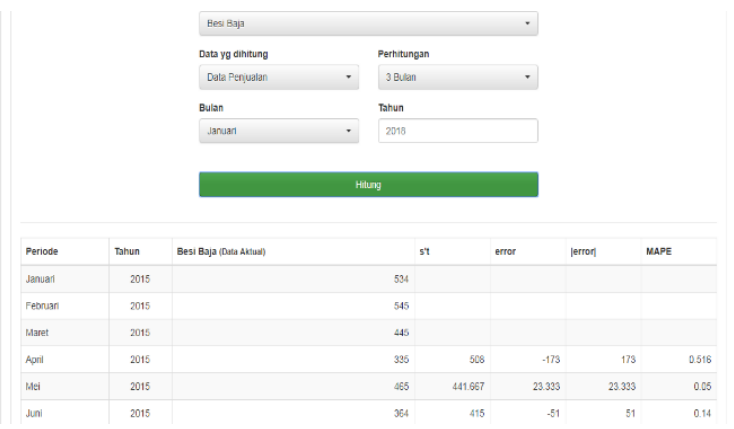

Gambar 4.6 Halaman Penentuan

Periode Januari 2016 dengan perhitungan per 3 bulan

Pada contoh dalam pengujian perhitungan forecast per 3 bulan periode untuk menghitung forecast pada periode Januari 2016 Lihat pada sebagai berikut Gambar 4.7.
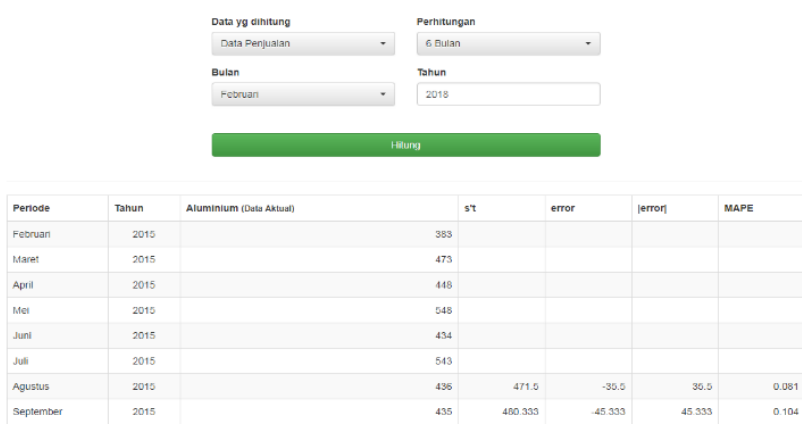

Gambar 4.7 Halaman Penentuan

Orde Periode Februari 2016

dengan perhitungan per 6 bulan

\subsubsection{Halaman Forecast}

Halaman laporan merupakan halaman yang berisi kumpulan dari data produksi besi yang sudah melaui proses forecast. Pada halaman laporan bisa langsung di cetak dalam bentuk word. Halaman laporan dapat dilihat pada Gambar 4.8

\section{SISTEM PREDIKSI PENJUALAN BARANG BEKAS FABRIKASI}

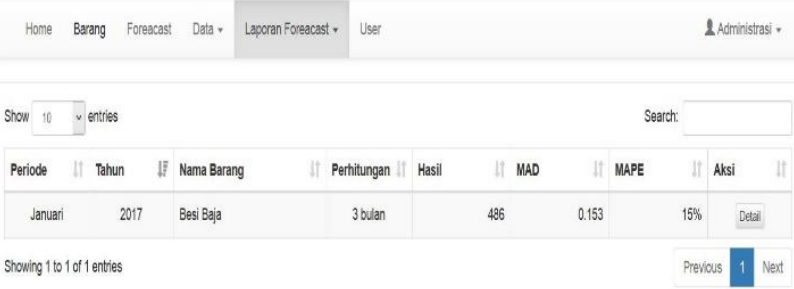

Gambar 4.8 Halaman Laporan

Form Tambah Data penjualan pada Gambar 4.9 Halaman Form tambah data penjualan digunakan untuk menambahkan data jumlah per periode (bulan).

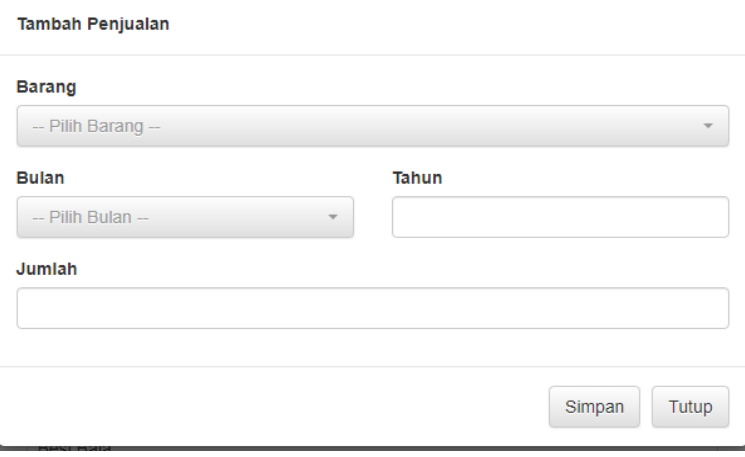

Gambar 4.9 Tambah Data penjualan

Form Forecast pada Gambar 4.10 Halaman tambah forecast digunakan untuk menghitung forecast data penjualan fabrikasi. Perhitungan forecast dapat dilakukan dari memasukkan barang, bulan, tahun dan memilih acuan sesuai keinginan pengguna dari orde per 3, 6, 9, 12 bulan kemudian klik tombol simpan untuk memproses perhitungan forecast 
INDEXIA: Informatic and Computational Intelegent Journal

Achmad Rifki Rusady, Harunur Rosyid

Sistem Prediksi Penjualan Barang Bekas Fabrikasi Di Cv. Indro Jaya Dengan Metode Single Moving Average

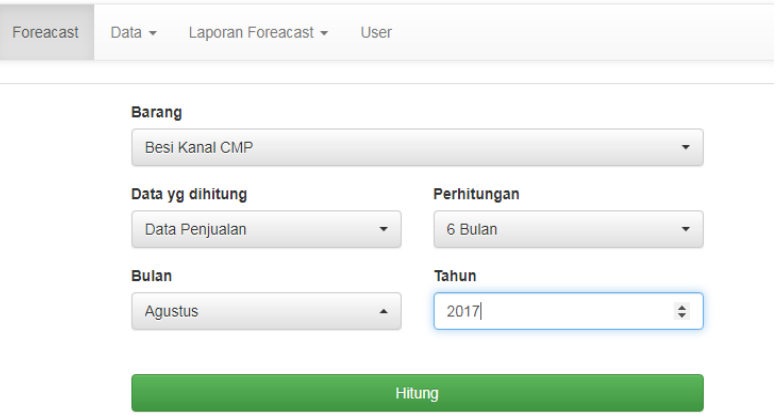

Gambar 4.10 Tambah Data forecast

Pengaturan akun disini hanya mengganti username, nama, password 1 lama dengan password yang baru dan konfirmasi password baru seperti Gambar 4.11.

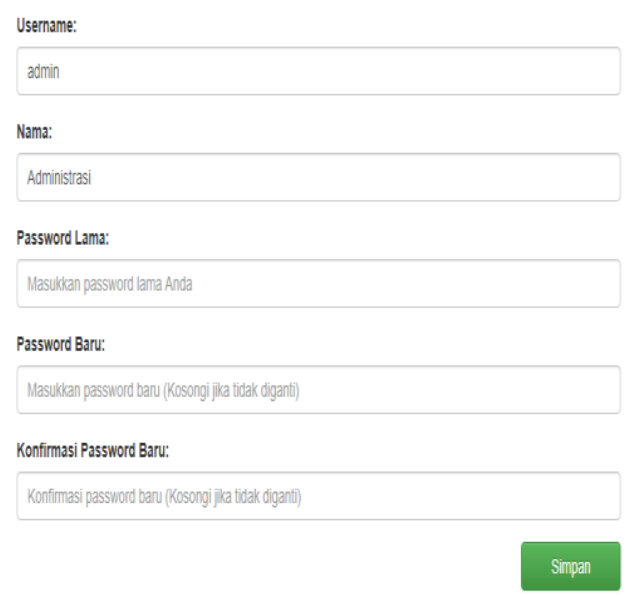

Gambar 4.11. Pengaturan akun

\subsection{Analisa Hasil Pengujian Sistem}

Pada Analisa hasil pengujian sistem penulis menggunakan data penjualan barang bekas fabrikasi di CV. Indrojaya selama 3 tahun yaitu menggunakan acuan orde $3 \times 3$ (3 bulan sebelumnya), orde $4 \times 4$ ( 6 dan 9 bulan sebelumnya), dan orde $6 x 6$ (12 sebelumnya) untuk menentukan peramalan bulan selanjutnya mulai bulan Januari 2014 - Januari 2017 selama 3 tahun untuk mengetahui hasil forecast manakah yang terbaik dengan memperoleh nilai kesalahan peramalan Mean Absolut Deviation (MAD) terkecil dan Mean Absolut Percentage Error (MAPE). Berikut ini adalah analisa hasil pengujian sitem 3 tahun:

\subsubsection{Pengujian}

a. Pengujian Untuk Januari 2014-Januari 2017

Tabel 4.1 Hasil Pengujian Untuk Bulan Mei 2014 orde $3 \times 3$ (3 bulan sebelumnya).

\begin{tabular}{|c|c|c|c|c|c|c|c|c|}
\hline No & Bulan & Tahun & $\begin{array}{c}\text { Jml } \\
\text { Penjualan } \\
\text { Besi }\end{array}$ & St. & S"t & at & bt & $\begin{array}{c}\text { Forecas } \\
t \\
\text { (Ft) }\end{array}$ \\
\hline 1 & Tanuari & 2014 & 428 & & & & & \\
\hline 2 & Februari & 2014 & 432 & & & & & \\
\hline 3 & Maret & 2014 & 482 & & & & & \\
\hline 4 & Apri & 2014 & 338 & 447.333 & -109.333 & 109.333 & 0.323 & \\
\hline 5 & Mei & 2014 & & & & & & 417.333 \\
\hline
\end{tabular}

Dari tabel diatas didapatkan hasil forecast bulan mei 2014 dengan nilai dengan orde 3x3 (3 bulan sebelumnya). Dari tabel diatas dapat dilihat nilai hasil pengujian prediksi dan kesalahan MAD \& MAPE sebagai berikut :

Tabel 4.2 Hasil Perhitungan MAD dan MAPE Untuk Bulan Desember 2014 orde 3x3 (3 bulan sbelumnya).

\begin{tabular}{|c|c|c|c|c|c|c|c|}
\hline Periode & Tahun & Aluminium (Dasta Aktual) & & st & error & |error| & MAPE \\
\hline Desember & 2014 & & 533 & & & & \\
\hline Januari & 2015 & & 479 & & & & \\
\hline Febuari & 2015 & & 383 & & & & \\
\hline Maret & 2015 & & 473 & 465 & 8 & 8 & 0.017 \\
\hline Apert & 2015 & & 448 & 445 & 3 & 3 & 0.007 \\
\hline Mel & 2015 & & 548 & 434.667 & 113.333 & 113.333 & 0.207 \\
\hline Juni & 2015 & & 434 & 489.667 & .55 .667 & 55.667 & 0.128 \\
\hline Jull & 2015 & & 543 & 476.667 & 66.333 & 66.333 & 0.122 \\
\hline Agusus & 2015 & & 436 & 500.333 & .72 .333 & 72.333 & 0.166 \\
\hline September & 2015 & & 435 & 471 & -36 & 36 & 0.083 \\
\hline Oxtober & 2015 & & 342 & 471.333 & -129.333 & 129.333 & 0.378 \\
\hline November & 2015 & & 438 & 404.333 & 33.667 & 33.667 & 0.077 \\
\hline Desember & 2015 & & 544 & 405 & 139 & 139 & 0.256 \\
\hline Januari & 2016 & & 594 & 441.333 & 152.667 & 152.667 & 0.257 \\
\hline Febraari & 2016 & & 435 & 525.333 & -90.333 & 90.333 & 0.208 \\
\hline Maret & 2016 & & 436 & 524,333 & .88 .333 & 88.333 & 0.203 \\
\hline April & 2016 & & 347 & 488.333 & -141.333 & 141.333 & 0.407 \\
\hline Mel & 2016 & & 438 & 406 & 32 & 32 & 0.073 \\
\hline Juni & 2016 & & 458 & 407 & 51 & 51 & 0.111 \\
\hline Jull & 2016 & & 348 & 414.333 & 66.333 & 66.333 & 0.191 \\
\hline Agustus & 2016 & & 450 & 414.667 & 35.333 & 35.333 & 0.079 \\
\hline Septenber & 2016 & & 459 & 418.667 & 40.333 & 40.333 & 0.088 \\
\hline Oktober & 2016 & & 485 & 419 & 66 & 66 & 0.136 \\
\hline November & 2016 & & 455 & 464.667 & -9.667 & 9.667 & 0.021 \\
\hline Desember & 2016 & & 543 & 466.333 & 76.667 & 76.667 & 0.141 \\
\hline \multirow[t]{5}{*}{ Desember } & 2017 & & & 494.333 & & & \\
\hline & & & & & & MAD & MAPE \\
\hline & & & & Total & & 1506.665 & 3.356 \\
\hline & & & & Total / Data / & a Aktual (25) & 60.267 & 0.153 \\
\hline & & & & \multicolumn{3}{|c|}{ Hasil MAPE (\%) } & $15.3 \%$ \\
\hline
\end{tabular}

fabrikasi untuk 
INDEXIA: Informatic and Computational Intelegent Journal

Achmad Rifki Rusady, Harunur Rosyid

Sistem Prediksi Penjualan Barang Bekas Fabrikasi Di Cv. Indro Jaya Dengan Metode Single Moving Average

Januari 2014-Desember 2017 dengan menggunakan perhitungan data acuan orde $3 \times 3$ (3 bulan sebelumnya) selama 3 tahun dengan menghasilkan nilai MAD 3,356 dan MAPE 15.3\%.

Tabel 4.3 Hasil Pengujian Untuk Bulan Agustus 2015 orde $4 \times 4$ (6 bulan sebelumnya).

\begin{tabular}{|c|c|c|c|c|c|c|}
\hline Januai & 2015 & 479 & 4926 & .13 .5 & 135 & 0.028 \\
\hline Faxyali & 2015 & 333 & 491.167 & -40.157 & 1081.167 & 0.282 \\
\hline lieres & 2015 & 473 & 466 & $?$ & 7 & 0.015 \\
\hline April & 2015 & 483 & 4695 & -15.5 & 156 & 0.035 \\
\hline ist & 2015 & 548 & 460 & 73 & 79 & 0.144 \\
\hline Juni & 2015 & 434 & 4730 & 48.333 & 4330 & 0.1 \\
\hline JuI & 2015 & 543 & 450203 & 82.167 & 82167 & 0.151 \\
\hline Agustus & 2015 & & 471.5 & & & \\
\hline
\end{tabular}

Dari tabel diatas didapatkan hasil forecast bulan Januari hingga Agustus 2015 dengan nilai 22,333. dengan orde $4 \times 4$ (6 bulan sebelumnya)Dari tabel diatas dapat dilihat nilai hasil pengujian prediksi dan kesalahan MAD \& MAPE sebagai berikut :

Tabel 4.4 Hasil Perhitungan MAD dan MAPE Untuk Bulan Desember 2017 orde 4x4 (6 bulan sebelumnya).

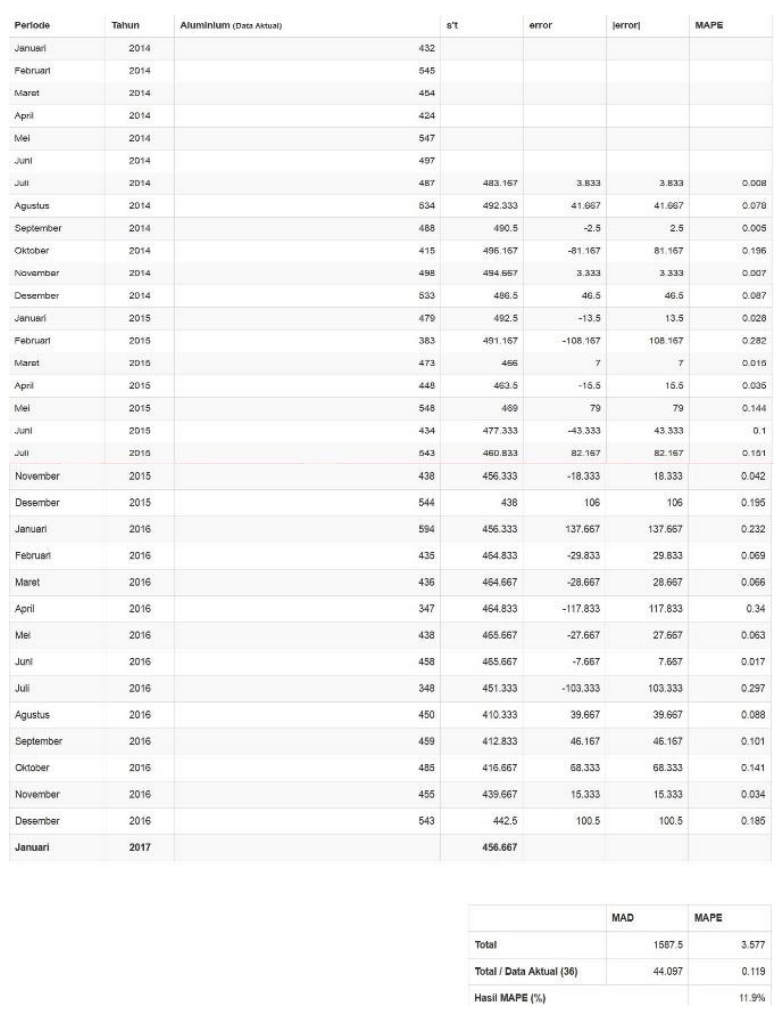

Jadi perhitungan forecast penjualan besi fabrikasi pada periode Desember 2014 - Januari
2017 dengan menggunakan perhitungan data acuan orde $4 \times 4$ (6 bulan sebelumnya) selama 3 tahun dengan menghasilkan nilai MAD 3,577 dan MAPE $11,95 \%$.

Tabel 4.5 Hasil Pengujian Untuk Bulan Desember 2015 orde 6x6 (12 bulan sebelumnya).

\begin{tabular}{|c|c|c|c|c|c|c|}
\hline laruani & 2015 & 479 & 497.833 & 8830 & 8.633 & 0018 \\
\hline Fetruarif & 2015 & 303 & 491.75 & 100.75 & 10875 & 0284 \\
\hline liare & 2015 & 473 & 47825 & 5.5 & 525 & 0.011 \\
\hline Api & 2015 & 48 & 479833 & 31835 & 31.033 & 0071 \\
\hline Vie & 2015 & 548 & 491.833 & 68.167 & 69.167 & 0.121 \\
\hline Jiri & 2015 & 424 & 481.977 & 47917 & 47.917 & 0.11 \\
\hline Jail & 2015 & 543 & 47667 & 663330 & 6.233 & 0.122 \\
\hline Agosiss & 2015 & 436 & 491.333 & 45330 & 45.33 & 0.104 \\
\hline Sepparbor & 2015 & 435 & 473.167 & 38.167 & 39.167 & 0.088 \\
\hline Oxictarer & 2015 & 34 & 48675 & 166.75 & 126.75 & 0.371 \\
\hline Nourber & 2015 & 438 & 42657 & 24667 & 24.67 & 0056 \\
\hline Desermber & 2015 & & 457.667 & & & \\
\hline
\end{tabular}

Dari tabel diatas didapatkan hasil forecast bulan desember 2015 dengan nilai 457.667 dengan orde $6 x 6$ (12 bulan sebelumnya). Dari tabel diatas dapat dilihat nilai hasil pengujian prediksi dan kesalahan MAD \& MAPE sebagai berikut :

Tabel 4.6 Hasil Pengujian MAD dan MAPE Bulan Januari 2017 orde $6 \times 6 \quad(12$ bulan sebelumnya).

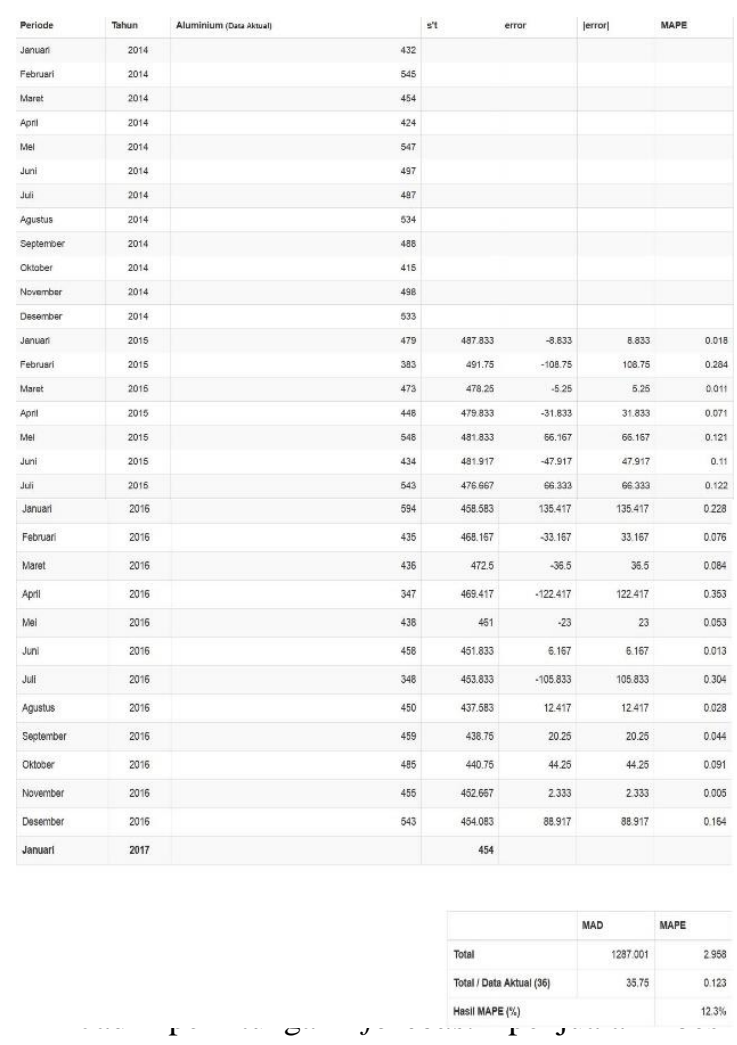

fabrikasi pada periode Desember 2014 - Januari 
2017 dengan menggunakan perhitungan data acuan orde $6 z 6$ (11 bulan sebelumnya) selama 3 tahun dengan menghasilkan nilai MAD 2,958 dan MAPE $12,3 \%$.

\subsection{Keberhasilan}

Pengujian bulanan ini dilakukan pada 1 lokasi tempat penjualan besi fabrikasi dengan menggunakan acuan peramalan orde $3 \times 3$ (3 bulan sebelumnya), orde $4 \times 4$ ( 6 bulan sebelumnya), orde 6x6 (12 bulan sebelumnya) untuk mendapatkan hasil peramalan dengan nilai kesalahan peramalan Mean Absolut Deviation (MAD) dan Mean Absolute Percentage Error (MAPE) terkecil dalam proses peramalan berdasarkan jumlah data periode yang berbeda dalam kurung waktu 3 tahun yaitu Januari 2015 sampai Desember 2017.

\subsubsection{Perbandingan Peramalan}

Informasi hasil peramalan produksi besi fabrikasi untuk kategori pengujian dengan menggunakan acuan peramalan orde $3 \times 3$ (5 bulan sebelumnya), orde $4 \times 4$ ( 7 bulan sebelumnya), orde 6x6 (11 bulan sebelumnya) dapat dilihat pada tabel 4.7 berikut:

Tabel 4.7 Perbandingan Error dalam Forecast Januari 2017

\begin{tabular}{|c|c|c|c|c|}
\hline No & $\begin{array}{c}\text { MAD \& } \\
\text { MAPE }\end{array}$ & $\begin{array}{c}\text { Orde } \\
\mathbf{6 x 6}\end{array}$ & $\begin{array}{c}\text { Orde } \\
\mathbf{4 x 4}\end{array}$ & $\begin{array}{c}\text { Orde } \\
\mathbf{3 x 3}\end{array}$ \\
\hline 1 & MAD & 2,958 & 3,577 & 3,356 \\
\hline 2 & MAPE & $12,3 \%$ & $11,95 \%$ & $15.3 \%$ \\
\hline
\end{tabular}

Berdasarkan Tabel 4.7 pengujian bulanan yang telah dilakukan didapatkan hasil menghasilkan kesalahan paling kecil dari orde $3 \times 3$, orde $4 \times 4$ dan $6 x 6$ yaitu dengan hasil nilai MAD 3,577dan nilai MAPE 11,95\% menggunakan data penjualan sebanyak 36 bulan dari bulan Januari 2015 - Desember 2017. Hal ini dipengaruhi oleh banyak nya data yang digunakan dalam proses peramalan semakin sedikit data yang digunakan maka kesalahan peramalan yang dihasilkan semakin rendah. Pengujian dengan nilai kesalahan peramalan terbesar adalah pengujian ketiga dengan menggunakan jumlah periode yang paling banyak. Hal ini menunjukkan bahwa data periode yang digunakan dalam peramalan akan sangat berpengaruh terhadap tingkat.

\section{KESIMPULAN DAN SARAN}

\subsection{Kesimpulan}

Setelah dilakukan pendefinisian masalah, analisis dan pembuatan system ini dapat diambil beberapa kesimpulan sebagai berikut :

1. Metode Single Moving Average ini dapat diimplementasikan untuk studi kasus prediksi penjualan bahan bekas fabrikasi bulan selanjutnya di CV. Indrojaya .

2. Berdasarkan pada hasil analisis pengujian sistem, dapat disimpulkan bahwa aplikasi ini dapat melakukan perhitungan prediksi. Jika banyaknya data yang digunakan dalam proses peramalan semakin sedikit, sehingga kesalahan prediksi atau error yang dihasilkan semakin rendah. Hal ini dibuktikan pada pengujian berdasarkan orde $3 \times 3$ (3 bulan sebelumnya) menghasilkan nilai MAD $=55.407$ dan MAPE $=13 \%$, pengujian kedua dengan orde $4 \times 4$ (6 bulan sebelumnya) menghasilkan nilai MAD = 44.907 dan MAPE $=11,9 \%$, pengujian ketiga dengan orde $6 \times 6$ (12 bulan sebelumnya) menghasilkan nilai MAD $=35.75$ dan MAPE $12 \%$. dan menghasilkan nilai rata-rata kesalahan peramalan lebih rendah jika dibandingkan dengan hasil uji pada pengujian yang jumlah datanya lebih banyak.

\subsection{SARAN}

Beberapa saran yang perlu penulis sampaikan untuk pengembangan sistem selanjutnya adalah :

1. Memperkenalkan sistem ini kepeda checker dan penanggung jawab agar dapat di ambil manfaatnya untuk memprediksi atau mengestimasi jumlah produksi besi fabrikasi pada periode selanjutnya.

2. Diharapkan adanya penelitian ini dengan metode trend linier lain untuk kemudian dibandingkan dengan metode Single Moving Average.

\section{DAFTAR PUSTAKA}

Ahlibaca "Pengertian Perancangan Sistem". 08 Maret 2017. From :

http://ahlibaca.com/pengertian-perancangansistem-berbagai-sumber

Basu Swastha Dan Irawan. 1997. Manajemen Pemasaran Modern. Yogyakarta : Liberty

Basu Swastha DH. 2004. Azas-azas Marketing. Liberty. Yogyakarta. 
INDEXIA: Informatic and Computational Intelegent Journal

Achmad Rifki Rusady, Harunur Rosyid

Sistem Prediksi Penjualan Barang Bekas Fabrikasi Di Cv. Indro Jaya Dengan Metode Single Moving Average

Basu Swastha. 2005 Manajemen Pemasaran Modern.

Liberty, Yogyakarta.

Boedijoewono Noegroho. 2001. Pengantar Statistik

Ekonomi Dan Bisnis Jilid 1. Yogykarta:UPP

AMP YKPN.

Boediono, Dr, Wayan Kaester, dr, Ir. MM. 2001. Teori

dan Aplikasi Statistika dan Probabilitas, Penerbit

Pt. Remaja Rosdakarya. Bandung

Budiasih Yanti. 2012. Statistika Deskriptif Untuk

Ekonomi Dan Bisnis. Tangerang:Jelajah Nusa.

Diana, dkk. 2015. Metode Single Moving Average.

Effendi Pakpahan, (2009). Volume Penjualan. Jakarta :

PT. Bina Initama Sejahtera.

Ihsan Muhammad. 2015. Perancangan Aplikasi Peramalan

Penjualan Motor Honda Menggunakan Metode

Least Square (Studi Kasus : Pt. Hd Motor 99 Gresik)

. Gresik: Universitas Muhammadiyah Gresik

Makridakis, Spyros, Steven C Wheelwright, Victor E.

Mcgee. 1999. Metode Dan Aplikasi Peramalan,

Jilid 1. Jakarta: Binarupa Aksara

Rahman Fathur. 2013. Sistem Informasi Manajemen

Penjualan Dan Peramalan Menggunakan

Metode Single Moving Average. Skripsi Thesis,

Uin Sunan Kalijaga.

Riana, Dwiza. 2012. Statistika Deskriptif Itu Mudah.

Tangerang: Jelajah Nusa.

Supranto,J. M.A. 2000. Statistik : Teori dan Aplikasi,

Edisi Keenam, Jilid 1, Erlangga, Jakarta.

Santoso, Singgih 2001. Aplikasi Excel dalam Statistik

Bisnis. Elex Media Komputindo. Jakarta.

Vanezia Ryanka Sutrisno. 2013 “Analisis Forecasting

Untuk Data Penjualan Menggunakan Metode

Single Moving Average Dan Single Exponential

Smoothing: Studi Kasus PT.Guna Kemas

Indah”.Fasilkom Universitas Indonesia. 